\title{
POLICIES FOR DECENTRALIZATION AND DEVELOPMENT OF HEALTH EDUCATION*
}

\author{
Lawrence W. Green**
}

\begin{abstract}
GREEN, L.W. Policies for decentralization and development of health education. Rev. Saúde públ., S.Paulo, 22: 217 - 20, 1988.

ABSTRACT: How the policy of action and professional standards have influenced the development and decentralization of health education is discussed. It is concluded that a review of policies both of developing as well as of developed countries could help to put some observations into a perspective that is closer to the Brazilian reality.
\end{abstract}

UNITERMS: Health education, trends. Health policy. Decentralization.

\section{INTRODUCTION}

Eight years ago, efforts were underway to define the role and minimum standards for the entry-level health education specialist, under the leadership of Dr. Helen Cleary 2,13,26. At the same time, our federal government was making a major commitment to health education with tenyear goals in disease prevention and health promotion ${ }^{24}$. I was asked by our Assistant Secretary for Health to take a leave of absence from my university to direct the federal office with major responsibility for the national policy initiative in health promotion. We defined health promotion as "any combination of health education and related organizational, economic and environmental supports for behavior conducive to health" $7,9,10$.

My purpose here is to draw from our American experience to see how policy has influenced the development and decentralization of health education, and how professional standards, in turn, have influenced policy. To apply this to Brazil, I will draw from my more recent experience in preparing for World Health Organization (WHO) the report of the Technical Discussions of the 36th World Health Assembly which were held in 1983 on the topic, "New Policies for Health Education in Primary Health Care" ${ }^{8}$. This review of policies in the developing as well as developed countries around the world should help put my observations from the United States into a perspective that is closer to the Brazilian reality.

\section{The Professional Development Cycle}

Behind every policy is a theory. Sometimes the theory is explicit, such as the theory that participation of people in setting their own priorities and goals will enhance their commitment to the programs. This theory has provided the justification for many policies that support health education ${ }^{8}$. Other theories are sometimes implicit in policies, such as the economic theories of capitalism and socialism. Long-standing policies are based on well-grounded theories and consistent with prevailing cultural ideologies; short-term policies are based more on political ideologies with implicit theories.

Policies, in turn, influence professional practice. Professionals and research scientists evaluate practice, which leads to modifications of theory, as shown in Figure 1. Evaluation also provides immediate feedback to practice. Training, the fifth element, shown in the middle of the cycle, is influenced directly by theory, policy and evaluation, and directly influences practice ${ }^{11}$.

In the short history of the recent disease prevention and health promotion initiative in the United States, we saw a theory of "lifestyle as a major determinant of health" become policy emphasizing health education to modify lifestyle. A rapid escalation of health education programs and practice led to increased evaluation. The evaluations showed that complex lifestyles of smoking, sedentary living and substance abuse did not change readily in response to simple health education messages. This led to an elaboration of the theories and consequent modification of the policies supporting health promotion programs. More emphasis was then placed on laws restricting smoking in public places, penalizing drunk drivers and drug dealers more

* Presented at the Conference on Minimum Standards in Health Education Practice, Itu, S.Paulo, Brazil, 1987.

4. Center for Health Promotion Research and Development. P.O. Box 20186. Houston, Texas. 77225 - USA. 
severely, and providing incentives for worksite health promotion programs ${ }^{16,19}$.

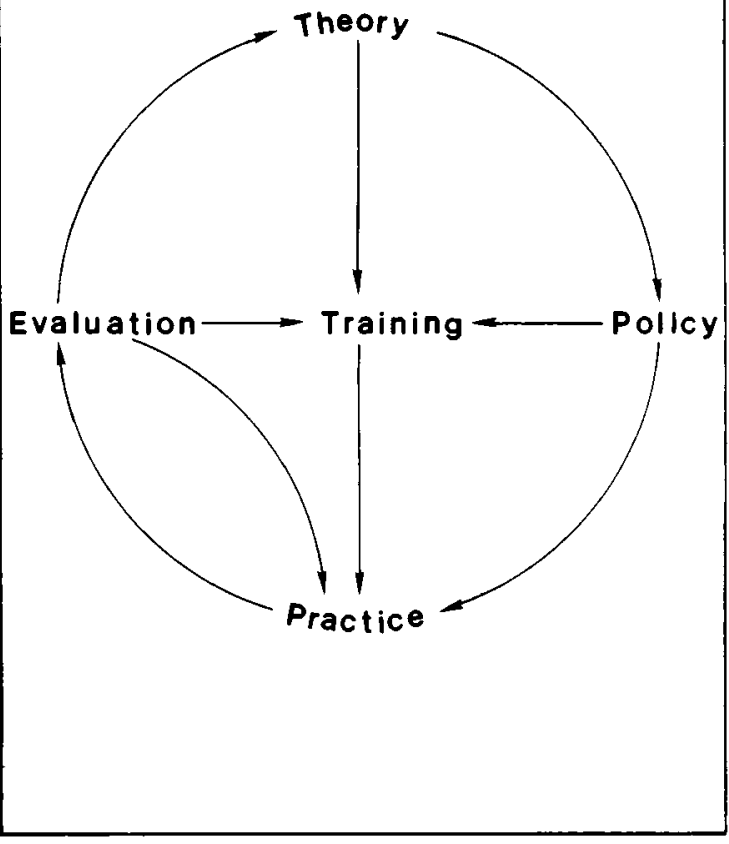

Fig. 1 - The professional development cycle.

The initial policy initiatives also resulted in a rapid increase in the number of professional training programs in health education. With the modification of the policies described above came modifications in training and consequently in practice. We see in the American example, then, a series of cyclical patterns of relationships among theory, policy, training, professional practice and evaluation. Significant change in any one of these has the potential of affecting all the others. Obviously, policy changes exert the most powerful influence, but professional initiatives to change the training and practice of health education specialists also can exert their indirect influence on policy.

\section{The Cycle of Professional Poverty}

Health education in most countries has long labored under an impoverished state of policy support ${ }^{17}$. Inadequate support has led to programs and practices that attempted to meet too many needs with too few resources. Objectives were vague, consequently practice was diffuse and not well targeted or focused. The results of scattered efforts were barely measurable, and without measurable results, the case could barely be made for more support ${ }^{6}$.

\section{Breaking the Cycle of Professional Poverty}

The cycle of professional poverty for health education has been broken at five points in recent years in the United States. The first has been with improved and increased research and evaluation ${ }^{11}$.

This began most notably with the family planning and immunization programs of the 1960s, strengthened with the hypertension and other patient education programs of the 1970s, and continues with increasingly complex community health education and health promotion programs for chronic disease control in the $1980 \mathrm{~s}^{3,4}$.

The second intervention that helped to break the cycle of professional poverty for health education was the increased involvement of other disciplines in the study of health education problems. The growing interest of sociologists, anthropologists and demographers during the international health and family planning movements of the 1950 s and the poverty programs of the 60 s stimulated new ways of analyzing health education problems in terms of social structural, cultural and demographic realities and theories ${ }^{5}$. The emergence of psychologists in the Public Health Service to study the reasons people accepted $x$-ray screening for tuberculosis in the 1950 s $^{14}$ and immunizations in the $1960 \mathrm{~s}^{23}$, built upon the earlier value-expectancy theories of Lewin $^{18}$ and others ${ }^{1}$ to produce the Health Belief Model. This model has given health education a more specific theoretical base to guide policy and practice than did the earlier philosophical and social theories 20,25 .

But sociology remained a wellspring of concepts and theories guiding public health education. Community organization and diffusion theories contributed significantly to the formulation of policies and professional training programs in health education, and through these to the practice of health education ${ }^{12}$.

The third point of intervention on the professional poverty cycle for health education was the preparation of a series of significant policy analyses in the 1970s. These began with the President's Commitee on Health Education, which reported its findings in 197121; continued through "White Papers" by the American Hospital Association, the Health Insurance Institute of America, the American College of Preventive Medicine, and others; and culminated with the Institute of Medicine's background papers for the Surgeon General's Report on Health Promotion and Disease Prevention in 197915. The case was built systematically for greater policy emphasis on health education. 


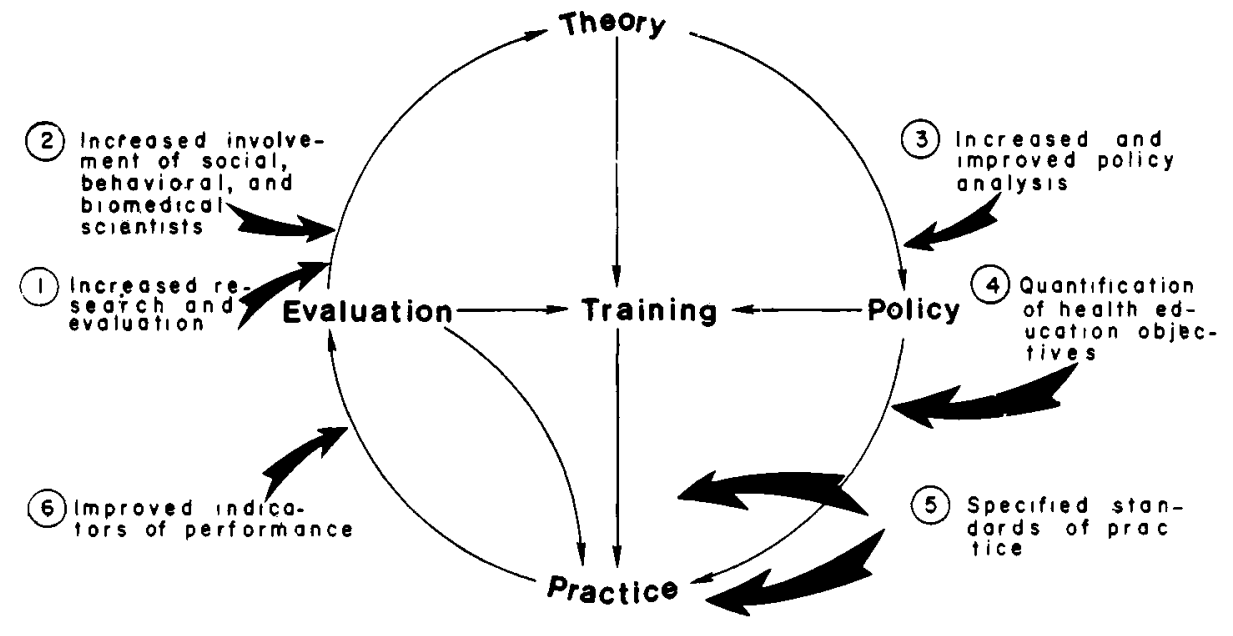

Fig. 2 - Six points intervention that broke the cycle of poverty in health education.

The third point of intervention came with the new policy initiatives stimulated by the foregoing analyses. In particular, health education was given a place in the Office of the Assistant Secretary of Health where policy is shaped and promulgated for the U.S. Public Health Service. This Office of Disease Prevention and Health Promotion, together with the Centers for Disease Control which coordinates relationships between federal and state health agencies, sponsored a consensus process to produce quantitative objectives for the nation in disease prevention and health promotion 22 . These objectives constituted policy for a decade, reaffirmed by the new federal administration in 1981 with instructions to the agencies of the Public Health Service to prepare their budget requests by showing how their budgets would contribute to accomplishment of the objectives by 1990 .

\section{The Importance of Professional Training and Standards of Practice}

Central to the cycles show in Figures 1 and 2 is training. Health education depends for its sucess on the adaptation of theory and policy to produce appropriate programs and effective delivery of resources at regional and local levels. Policy can only improve the quality of health education if those who implement the policies know how to transform them into effective programs. This requires knowledge, skill and professional discipline. These require training.

Training seeks to produce professional who can meet at least minimum standards of practice. This is what we have been struggling to define over the past several years in the United States.

GREEN, L.W. Políticas de descentralizaçăo e desenvolvimento da educação em saúde. Rev. Saúde públ., S.Paulo, 22: 217 - 20, 1988.

RESUMO: Discute-se como a polrtica de ação e $\infty$ padröes profissionais têm influenciado o desenvolvimento e a descentralização da Educaçăo em Saúde. Conclui-se que estudos sobre política de açăo em paises desenvolvidos e em desenvolvimento contribuem para observaçðes a partir de uma perspectiva mais próxima à realidade brasileira.

UNITERMOS: Educaçāo em saúde, tendências. Política de saúde. Descentralizaçăo. 


\section{REFERENCES}

1. BECKER, M., ed. The health belief model and personal health behavior. Hlth Educ. Monogr., 2 (4) 1974.

2. CLEARY, H. P. Issues in the credentialing of health education specialists: a review of the state of the ant. Adv. Hlth Educ. Promotion, 1 (Part A): 129-54, 1986.

3. CULLEN, J.; FOX, B.; ISOM, R., ed. Cancer: the behavioral dimensions. New York, Raven Press, 1976.

4. ENELOW, A. J. \& HENDERSON, J. B., eds. Applying behavioral science to cardiovascular risk. New York, American Heart Association, 1975.

5. GOODENOUGH, W. H. Cooperation in change: an anthropological approach to community development. New York, Russell Sage Foundation, 1963.

6. GREEN, L. W. Determining the impact and effectiveness of health education as it relates to federal policy. Hlth Educ. Monogr., 6: 28-66, 1978.

7. GREEN, L. W. Healthy people: the Surgeon General's Report and the prospects. In: McNemey, W. K., ed. Working for a healthier America. Cambridge, Mass., Ballinger Publ., 1980.

8. GREEN, L. W., ed. New policies for health education in primary health care. Geneva, World Health Organiza. tion, 1986. (WHO/HED/86.1).

9. GREEN, L W. A participant-observer during a period of professional change. In: Cleary, H. P. et al., eds. Advancing health through education: a case study ap. proach. Palo Alto, Cal., Mayfield Publ., 1984. p. 37481.

10. GREEN, L. W. \& JOHNSON, K. W. Health education and health promotion. In: Mechanic, D., ed. Handbook of health, health care, and the health professions. New York, John Wiley, 1983. p. 744-65.

11. GREEN, L. W. \& LEWIS, F. M. Measurement and evaluation in health education and health promotion. Palo Alto, Cal., Mayfield Publ., 1986.

12. GREEN, L. W. \& McALISTER, A. L Macro-intervention to support health behavior: some theoretical perspectives and practical reflections. Hith Educ. Quart., 11 323-39, 1984

13. GUIDELINES for the preparation and practice of professional health educators. Hlth Educ. Monogr., 5: 75-89, 1977.

14. HOCHBAUM, G. Public participation in medical screen. ing programs: a sociopsychological stucty. Washington,
D. C., U. S. Government Printing Office, 1959. (Public Health Service Publication, 572).

15. INSTITUTE OF MEDICINE. Healthy people: background papers for the Surgeon General's Report on health promotion and disease prevention. Washington, D. C., Public Health Service, 1979.

16. KOLBE, L. J. \& IVERSON, D. C. Integrating school and community efforts to promote heslth: strategies, policies and methods. Hygie: Int. J. Hlth Educ., 2: 40-7, 1983.

17. KREUTER, M. W. \& GREEN, L. W. Evaluation of school health education: identifying purpose, keeping perspective. J. Sch. Hlth, 48: 228-35, 1978.

18. LEWIN, K. A dynamic theory of personality: selected papers. New York, MoGraw-Hill, 1935.

19. MCALISTER, A. L. \& GREEN, L. W. New approaches to the promoxion of public health and safety. Publ. Affairs Comment., 30: 1-11, 1984.

20. MILLER, N. E.; MATARAZZO, J. D.; WEISS, S. M.; HERD, J. A.; WEISS, S., eds. Behavioral health: a handbook of health enhancement and disease prevention. New York, Jonh Wiley, 1984.

21. PRESIDENT'S COMMITEE ON HEALTH EDUCATION. Report of the President's Committee Health Education. New York, National Center for Health Education, 1971.

22. PROMOTING Health/Preventing Disease: Objectives for the Nation for 1990. Washington, D. C., Public Health Service, 1980.

23. ROSENSTOCK, I. M. Why people use health services. Milbank mem. Fd. Quart., 44: 94-127, 1966.

24. U. S. DEPARTMENT OF HEALTH AND HUMAN SERVICES. Healthy people: the Surgeon General's Report on the health promotion and disease prevention. Washington, D. C., Public Health Service, Office of Disease Prevention and Health Promotion, 1979.

25. WEISS, S.; HERD, A.; FOX, B.; eds. Perspectives of behavioral medicine. New York, Academic Press, 1981.

26. WOLLE, J. Activities of the APHA Advisory Committee on Community Health Education Accreditation. Hlih Educ, Monogr., 4: 276-7, 1976.

Received for publication: $14 / 8 / 1987$ Accepted for publication: 22/12/1987 